\title{
PEMBERDAYAAN MASYARAKAT MELALUI PENINGKATAN PENGETAHUAN, SIKAP, DAN PRAKTIK TERKAIT PERILAKU HIDUP BERSIH DAN SEHAT DI DESA DEWISARI, KECAMATAN RENGASDENGKLOK
}

\author{
Sandra Herlina $^{1}$, Nita Noriko ${ }^{2}$, Andri Hadiansyah ${ }^{3}$, A. Mukramin Yusuf ${ }^{4}$ \\ ${ }^{1}$ Program Studi Bahasa dan Kebudayaan Jepang, Fakultas Ilmu Pengetahuan Budaya, \\ Universitas Al Azhar Indonesia, Jalan Sisingamangaraja, Kompleks Masjid Agung al Azhar, \\ Kebayoran Baru, Jakarta Selatan 12110 \\ ${ }^{2}$ Program Studi Biologi, Fakultas Sains dan Teknologi, Universitas Al Azhar Indonesia, \\ Jalan Sisingamangaraja, Kompleks Masjid Agung Al Azhar, Kebayoran Baru, Jakarta Selatan 12110 \\ ${ }^{3}$ Program Studi Psikologi, Fakultas Psikologi dan Pendidikan, Universitas Al Azhar Indonesia, \\ Jalan Sisingamangaraja, Kompleks Masjid Agung Al Azhar, Kebayoran Baru, Jakarta Selatan 12110 \\ ${ }^{4}$ Program Studi Gizi, Fakultas Sains dan Teknologi,Universitas Al Azhar Indonesia, \\ Jl. Sisingamangaraja, Kompleks Masjid Agung Al Azhar, Kebayoran Baru, Jakarta Selatan 12110 \\ Email Penulis Korespondens: andi.yusuf@uai.ac.id
}

\begin{abstract}
Abstrak
Air sungai citarum masuk dalam kategori tercemar berat dan menjadi ancaman kesehatan masyarakat karena dapat mengakibatkan berbagai macam penyakit. Hal ini seiring dengan masih ditemukannya warga yang menggunakan air sungai untuk kehidupan sehari-hari, misalnya untuk Mandi, Cuci, Kakus. Kesadaran masyarakat dalam mempraktikan Perilaku Hidup Bersih dan Sehat (PHBS) masih rendah. Hasil pengamatan menunjukkan bahwa masyarakat masih menggunakan air kotor untuk kegiatan sehari-haridisebabkan oleh belum tersedianya sarana dan prasarana pengolahan air kotor menjadi air bersih. Kegiatan ini dilaksanakan di Yayasan Yatim Al-Muhayya dengan sasaran masyarakat sekitar yayasan untuk dapat berkontribusi dalam Pelatihan, Pendampingan, dan Peningkatan pengetahuan tentang praktik PHBS rumah tangga. Permasalahan yang terdapat di daerah mitra dapat diselesaikan dengan melibatkan peran serta masyarakat dalam mengatasinya. Peningkatan pengetahuan ditandai dengan hasil pre dan post test terkait PHBS pada masyarakat sasaran. Selain itu, peningkatan penggunaan air bersih, pelatihan pembuatan filter air yang sederhana dan aplikatif sehingga membantu masyarakat dalam mengakses air bersih. Hasil dari kegiatan ini menunjukkan terjadi peningkatan pengetahuan pada ibu setelah diberikannya informasi secara menyeluruh terkait PHBS. Adapun penggunaan filter air diharapkan mampu membantu memasok air yang bersih untuk kebutuhan keluarga.
\end{abstract}

Kata Kunci: Air bersih, Citarum, Filter, PHBS

\begin{abstract}
Citarum river water is categorized as heavily polluted and a threat to public health because it can cause various diseases. This is in line with the discovery of residents who use river water for daily life, for example for bathing, washing, toilet. Public awareness in practicing clean and healthy life behavior is still low. Observation results indicate that the community still uses dirty water for daily activities due to the unavailability of facilities and infrastructure for processing dirty water into clean water. This activity was carried out at the Yayasan Yatim Al-Muhayya with the target community around the foundation to be able to contribute to the Training, Assistance, and Increased knowledge about clean and healthy life behavior in the household. Problems in partner areas can be resolved by involving community participation in overcoming them. Knowledge enhancement is marked by the results of pre and post-tests related to clean and healthy life behavior in the target community. Also
\end{abstract}


Besides, increasing the use of clean water, training in making water filters that are simple and applicable also helps the community in accessing clean water. The results of this activity showed an increase in knowledge to mothers after giving comprehensive information related to clean and healthy life behavior. The use of water filters is expected to help supply clean water for family needs.

Keywords: Clean water, Citarum, Filter, PHBS

\section{PENDAHULUAN}

Peraturan Presiden Republik Indonesia Nomor 15 Tahun 2018 tentang Percepatan Pengendalian Pencmaran dan Kerusakan Daerah Aliran Sungai Citarum dikeluarkan mengingat peran Sungai Citarum merupakan sungai stategis nasional. Partisipasi masyarakat diperlukan dalam upaya pencegahan, penanggulangan kerusakan dan pencemaran, serta pemulihan daerah aliran sungai.

Kecamatan Rengasdengklok adalah salah satu kecamatan yang secara langsung dialiri oleh Sungai Citarum. Penduduk Kecamatan Rengasdengklok masih sangat bergantung pada aliran Sungai Citarum untuk kegiatan seharihari, seperti kegiatan Mandi Cuci Kakus (MCK). Kondisi air yang kotor dan tercemar tidak menjadi penghalang bagi warga untuk tetap memanfaatkan air sungai citarum. Limbah domestik atau limbah rumah tangga menyumbangkan dampak yang cukup besar bagi pencemaran Sungai Citarum. Jumlah limbah domestik yang dibuang langsung kebagian hulu Sungai Citarum adalah sebesar 200,078 ton Biochemical Oxygen Demand (BOD) per harinya (Salim, 2002). Tercemarnya sungai Citarum juga dapat menyebabkan polusi air tanah, mempengaruhi kualitas air tanah, yang disebabkan karena adanya limbah domestik dan limbah industri. Hasil penelitian terkait menyebutkan limbah tersebut menyebabkan air sumur berwarna, berbau dan keruh selain itu air tidak memenuhi syarat secara mikrobiologi. Hal tersebut jelas membahayakan jika dikaitkan dengan kondisi masyarakat yang masih ada menggunakan air sumur gali untuk digunakan sehari-harinya (Widiyanto \& Kuswanto, 2015).

Berdasarkan hasil In Depth Interview dengan ibu - ibu kader kesehatan di desa Dewi Sari, kecamatan Rengasdengklok menunjukkan masyarakat masih menggunakan air sungai citarum untuk beraktivitas, misalnya untuk kebutuhan mencuci alat makan dan minum yang digunakan setiap hari padahal sangatlah berbahaya. Meskipun sebagian besar masyarakat sudah mengetahui bahwa limbah rumah tangga yang dibuang kealiran sungai akan memberikan dampak buruk bagi lingkungan dan kesehatan, namun masyarakat masih tetap melakukan aktivitas tersebut karena alas an kepraktisan.

Desa Dewi Sari merupakan desa yang terdampak oleh air sungai citarum, laporan kementerian lingkungan hidup menyebutkan kondisi air sungai Citarum 54\% tercemar berat, $23 \%$ tercemar sedang, $20 \%$ tercemar ringan dan hanya $3 \%$ yang memenuhi baku mutu. Saat ini masyarakat sekitar menjadikan sungai citarum sebagai salah satu tempat untuk kegiatan sehari-hari, hal tesebut disebabkan oleh belum tersedianya sarana dan prasarana pengolahan air kotor menjadi air bersih di sekitar masyarakat. Kondisi sanitasi, akses air bersih yang sulit disertai kurangnya pengetahuan terkait pola hidup bersih dan sehat dapat menimbulkan berbagai macam penyakit baik menular maupun penyakit tidak menular di Desa mitra yaitu desa Dewi Sari, kecamatan Rengasdengklok. Oleh karena itu sangat dibutuhkan program yang dapat membantu misalnya dalam bentuk pelatihan yang berujung meningkatnya pengetahuan serta kesadaran individu terkait kesehatan masyarakat.

\section{METODE PELAKSANAAN}

\section{Waktu dan Tempat Pelaksanaan}

Kegiatan dilaksanakan di Desa Dewi Sari, Kecamatan Rengasdengklok pada bulan Februari - Juli 2019. Pelaksanaan kegiatan pengabdian masyarakat dilakukan melalui proses pelatihan, pengadaan, pengelolaan, pembinaan dan pendampingan untuk meningkatkan kesadaran PHBS rumah tangga dan kemampuan membuat filter air. 


\section{Langkah Pelaksanaan}

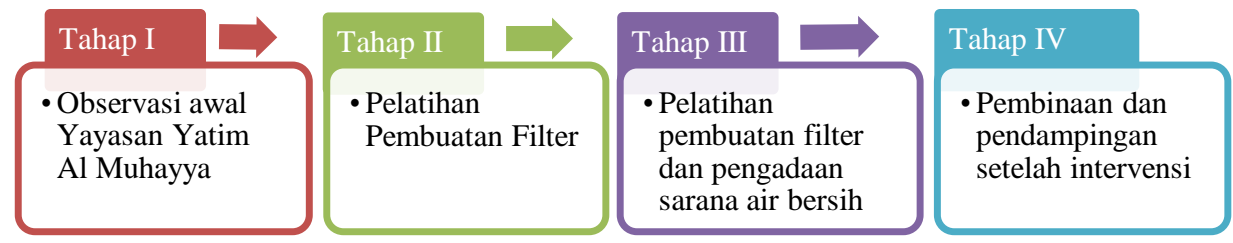

Gambar 1. Alur pelaksanaan kegiatan di daerah mitra Yayasan Al Muhayya

Kegiatan yang dilaksanakan dengan beberapa tahapan berdasarkan masalah dan target yang ingin dicapai melalui pelatihan, pengadaan, pembinaan dan pendampingan dengan output diantaranya sebagai berikut :

\section{Peningkatan Kesadaran Atas Perilaku Hidup Bersih Sehat Skala Rumah Tangga}

Peningkatan kesadaran atas perilaku hidup bersih dan sehat melalui pelatihan dan pembinaan yang disampaikan dengan menggunakan media stiker yang berisi tentang poin - poin yang perlu dilakukan untuk mencapai status kesehatan individu dan keluarga. Hasil kegiatan tersebut menunjukkan bahwa PHBS pada anak perlu didukung oleh keluarga untuk dapat menciptakan lingkungan yang sepenuhnya bersih dan sehat. Oleh sebabitu, pada kegiatan ini, peningkatan penanaman PHBS dilakukan pada sector rumah tangga.

\section{Peningkatan Penggunaan Air Bersih Melalui Pelatihan Pembuatan Filter Air}

Pembuatan filter air dilakukan dengan menggunakan system susunan filtrat. Air yang masuk akan dialiri melalui pasir (pasir pantai), kerikil pantai, arang, dan kapas aquarium. Air kotor yang keluar dari susunan filtrate akan menjadi bersih dan dapat digunakan untuk kegiatan sehari - hari. Kegiatan ini diharapkan akan membantu masyarakat dalam menyediakan air bersih dalam skala rumah tangga.

\section{HASIL DAN PEMBAHASAN}

\section{Peningkatan Kesadaran Atas Perilaku Hidup Bersih Sehat Skala Rumah Tangga \\ Perilaku Hidup Bersih dan Sehat (PHBS) adalah program yang diinisiasi oleh Kementerian Kesehatan dalam upaya}

menciptakan masyarakat yang mampu secara mandiri dengan kesadarannya menciptakan lingkungan yang sehat. Hasil penelitian menunjukkan terdapat pengaruh dan efek positif kegiatan penyuluhan terhadap peningkatan pengetahuan yang dilakukan, dan akan semakin baik jika dilakukan secara berkesinambungan (Wijayanti, Nuraini, \& Deharja, 2016). Kegiatan peningkatan pengetahuan ibu rumah tangga terkait PHBS dilakukan dalam bentuk pelatihan dengan menggunakan media stiker informatif yang dapat dibawa pulang dan ditempel di rumah untuk transfer informasi yang lebih luas pada seluruh anggota keluarga dari ibu rumah tangga tersebut. Pemberian stiker yang berisi pesan-pesan menjadi media yang mudah dan cukup efektif membangun kesadaran pada kultur masyarakat hari ini. Masyarakat lebih percaya dengan perkataan atau saran orang lain untuk melakukan sesuatu yang positif dengan desain dan gambar yang menarik.

Dengan menggunakan media stiker dan penyuluhan yang kemudian di sosialisasikan kemasyarakat terdekat oleh orang tua, tokoh masyarat. Hal ini berdampak pada munculnya kesadaran masyarakat terkait dengan perilaku hidup bersih dan sehat dikaitkan dengan kondisi sanitasi, akses air bersih dan lingkungan yang belum higien.

\section{Pendampingan dan Evaluasi}

Pada awal kegiatan sebelum pemberian materi, para ibu rumah tangga diberikan 10 rangkaian soal yang berkaitan dengan PHBS rumah tangga. Hasil pre-test dari 11 ibu rumah tangga menunjukkan bahwa rerata mereka hanya dapat menjawab 5 dari 10 pertanyaan yang diberikan. Setelah kegiatan pre-test dilakukan, ibu rumah tangga diberikan informasi secara menyeluruh terkait penjelasan masing - masing poin PHBS. Selama kegiatan, 
seluruh peserta terlihat antusias dan mengikuti kegiatan dengan baik. Di akhir kegiatan, hasil post-test menunjukkan peningkatan, yaitu rerata ibu rumah tangga dapat menjawab 8 dari 10 pertanyaan yang diajukan.

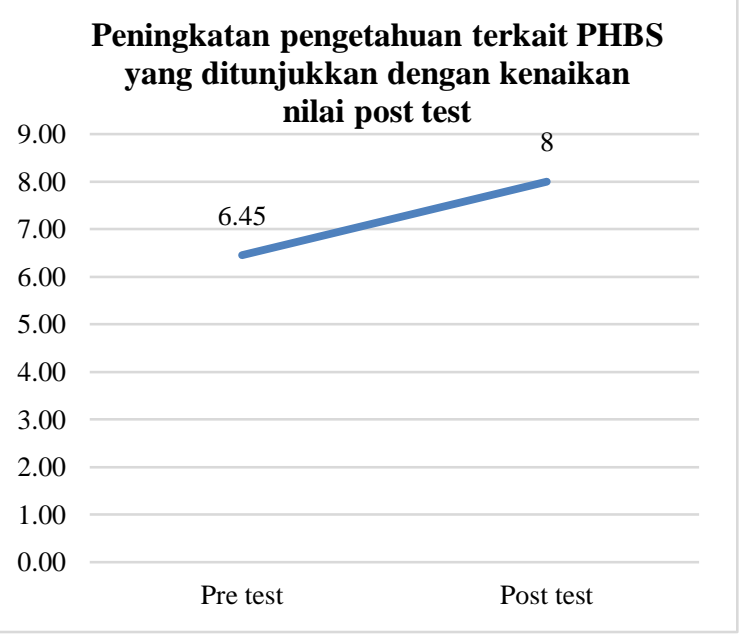

Gambar 2. Hasil pre-test dan post- test terkait PHBS rumah tangga

\section{Meningkatnya Penggunaan Air Bersih dan Pelatihan Pembuatan Filter Air}

Kebiasaan menggunakan dan mencuci tangan dengan air bersih disampaikan melalui penyuluhan dirangkaikan dengan cara pembuatan filter air skala rumah tangga yang sederhana dan aplikatif. Salah satu kendala yang sering dijumpai di masyarakat selain pengetahuanya itu tidak adanya sarana prasana misalnya air bersih untuk mewujudkan masyarakat sehat. Ibu rumah tangga yang memahami dan mempraktikan penggunaan filter air diharapkan mampu membantu memasok air yang bersih untuk keluarga.

Pembuatan filter air dilakukan dengan menggunakan system susunan filtrat. Hasil dari program ini menunjukkan masyakarat mampu mandiri misalnya dalam hal mendapatkan air bersih setelah dilakukan pelatihan. Filter yang telah jadi kemudian dialiri air dengan melewati pasir (pasir pantai), kerikil pantai, arang, dan kapas aquarium. Air kotor yang keluar dari susunan filtrate akan menjadi bersih dan dapat digunakan untuk kegiatan sehari hari. Kegiatan ini kemudian akan membantu masyarakat dalam menyediakan air bersih dalam skala rumah tangga. Ibu rumah tangga yang memahami dan mempraktikan penggunaan filter air juga diharapkan mampu membantu memasok air yang bersih untuk keluarga.

\section{SIMPULAN DAN SARAN}

Kegiatan peningkatan kesadaran pola hidup bersih dan sehat (PHBS) khususnya penggunaan air bersih di lingkungan rumah tangga dilaksanakan melalui beberapa tahapan diantaranya pelatihan dan pembinaan, pengelolaan, dan pendampingan. Hasil program menunjukkan adanya peningkatan pengetahuan ibu dilihat berdasarkan hasil pre-test yang dilakukan setelah diberikan informasi secara menyeluruh terkait poin poin PHBS. Selain itu meningkatnya penggunaan air bersih di masyarakat diharapkan melalui pelatihan pembuatan filter air skala rumah tangga yang sederhana dan aplikatif. Ibu rumah tangga yang memahami dan mempraktikan penggunaan filter air diharapkan mampu membantu memasok air yang bersih untuk keluarga. Perlu Kerjasama antar stakeholkder dalam penanggulangan limbah domestic misalkan dengan adanya Instalasi Pengolahan Air Limbah (IPAL) sehingga limbah rumah tangga dapat diolah terlebih dahulu sebelum dialirkan kesungai (Anwariani).

\section{UCAPAN TERIMAKASIH}

Terimakasih yang sebanyak-banyaknya kepada Tim LPPM Unversitas Al Azhar Indonesia yang telah memberikan pendanaan pada kegiatan pengabdian Masyarakat ini. Selain itu teman-teman Dosen Lintas Program Studi di Universitas Al Azhar Indonesia atas bantuan ide dan juga gagasannya dalam program ini.

\section{DAFTAR PUSTAKA}

Anwariani, D. Pengaruh Air Limbah Domestik Terhadap Kualitas Sungai. Jakarta: Fakultas Arsitektur Lanskap dan Teknologi Lingkungan, Universitas Trisakti. 
Salim, H. (2002). Beban Pencemaran Limbah Domestik Dan Pertanian Di DAS Citarum Hulu. Jurnal Teknologi Lingkungan .

Widiyanto, A. F., \& Kuswanto, S. Y. (2015). Polusi Air Tanah Akibat Limbah Industri dan Limbah Rumah Tangga. Jurnal Kesehatan Masyarakat, 246-254.
Wijayanti, R. A., Nuraini, N., \& Deharja, A. (2016). Pengaruh Penyuluhan Perilaku Hidup Bersih dan Sehat (PHBS) terhadap Pengetahuan Siswa di SMP Islam Mahfilud Duror Jelbuk. Seminar Hasil Penelitian dan Pengabdian Masyarakat Dana BOPTN Tahun 2016 (pp. 52-56). Jember: Politeknik Negeri Jember. 